\title{
Genus Krithe (Ostracoda) as a Proxy to Decipher Paleoceanography: A Global Review of the Genus
}

\author{
Mohammed Noohu Nazeer, K Radhakrishnan*, S M Hussain, V Sivapriya and A Rajkumar \\ Department of Geology, University of Madras, Chennai
}

Submission: July 22, 2019; Published: August 23, 2019

Corresponding author: K Radhakrishnan, Department of Geology, University of Madras, Chennai

Abstract

Highlighting the implication on paleoceanography using different species of the Ostracoda genus, Krithe across the globe is reviewed. Distribution of the genus in ocean sediments make them stand apart from all other Ostracoda genera for paleo-oceanographic evaluation. Salinity, temperature, nature of sediments and depth of the water column impacts the occurrence of the species. Preferably, the genus Krithe adapt cooler environment species and is useful as glacial and interglacial markers. Evidential from the studies, the different species of the genus Krithe are found occurring in different marine settings which marks them a valid species for biomonitoring the ocean bottom.

Keywords: Ostracoda; Krithe; Paleoceanography; Biomonitoring; Ocean bottom sediments; Morphometry

\section{Ostracoda (Krithe): A Prelude}

Ostracoda shells provide valuable insight into the ecology, hydrology, and aquatic chemistry of the environment [1]. The sensitivity of Ostracoda on feeble environmental fluctuations, make them a good marker for the interpretation of geological past. Distribution of Ostracod species varies with environmental conditions and sedimentological parameters. They can tolerate a wide salinity ranges [2] and hence, can occur in different environmental settings- marine, brackish, fresh waters, mangrove ecosystems and wet paddy fields. Ostracoda genera, Krithe is benthic pandemic fauna and is globally distributed [3] which diversely occur in deep sea, escalated greatly by its paleo environmental and paleo-oceanographic applications. Being a temperature dependent, salinity tolerant, mud loving genus and moreover a widely distributed genus across the oceans, the genus and its capacity stands unique for correlation of diverse ocean settings. The occurrence of Krithe is attributed to zone of upwelling and cold-water regions [4]. Different studies pertaining to the deep sea, multi proxy analysis in genera Krithe is handy. The exploration on paleoceanography using the genera is not receiving any mileage, because of lack of a proper compilation.

\section{Ostracoda genus Krithe as paleo-oceanographic biomarkers}

Being benthonic and abundant in ocean sediments (not observed in shallow tropical zone), Ostracoda genus Krithe marks its importance more than any other genera for paleooceanographic studies. Diversification of the genus Krithe is dominant beyond $1000 \mathrm{~m}$ water depth, in bathyal and abyssal zone [5]. Glacial- interglacial cycles are marked using abundance and diversity of Ostracoda genus Krithe from Eastern Equatorial Pacific [3]. Higher counts of genus Krithe represents a cooler temperature and vice versa. Krithe is common along the Upper Cretaceous region in northern Gulf coastal plain of North America. The nature of the sediments as well as the oxygen concentrations are the reason for the occurrence of the genus to a limited area, which implies on the paleoenvironment [6]. Extensive studies on East China and Yellow seas, wherein about 520 grab samples were collected and examined for the distribution pattern of Krithe and Parakrithe genera focusing mainly on the oceanographic changes [7].The genera were observed to occur in marginal marine conditions, and inner and middle shelf of the East China Sea and absence of the species addresses the lower salinity, higher temperature and coarser nature of the sediments and also the size of the shell varies with water temperature [8], which makes it useful for understanding bottom water chemistry and the temperature history of the ocean.

Deeper part of North Atlantic is dominated by diversified species of Krithe and the age determined aiding the microfossil assemblage is Eocene to Oligocene [9]. The significance of the temperature on shell growth and morphometry in taxa 
Krithe praetexta praetexta from North Atlantic, lights into the paleothermometric calculations. The taxonomy and geographical distribution of different species of Ostracod genus Krithe is restricted and its occurrence in the influence of cold waters also implied on the paleoecology of Brazilian margin. Distribution of Ostracoda from marine, brackish and coastal waters on 7 species (Krithe bartonensis, K. keyi, K. mersinensis, K. monosteracensis, $K$. praetexta, $K$. reniformis, $K$. similis) from Turkey region were examined to decipher the ecological calculations [10]. Biostratigraphic studies using different species of genus Krithe in New Zealand addresses on the diverse environmental settings [11]. An appraisal on the Ostracoda Krithe from deeper regions of Southern Indian Ocean explained the diversification effects of the genus and the paleoecological traits [12].

$\mathrm{Mg} / \mathrm{Ca}$ partitioning in Krithe shells from Norwegian Sea, Cape Hatteras, Gulf of Mexico revealed that bottom water temperatures are less than 30C in global oceans where the genus Krithe occurs. Stable isotopic studies by many researchers have inferred that Krithe is a cooler water genus. Branson \& Elderfield [13], used trace elements ( $\mathrm{Mg}$ and $\mathrm{Sr}$ ) and Electron Probe Micro Analysis to decipher paleothermometry along with the paleosalinity. The evolution of bottom ocean and the paleowater conditions can be decoded by the shell chemical studies using the genera. Morphometric calculations on Krithe iniqua and Krithe compressa from Monte San Nicola section deciphered the shape variations and potential differences between the two species [14]. The occurrence of Krithe bartonensis from Gebal Mokattam, Egypt along with several other species of Ostracoda and Foraminifera explained the paleo-oxygenation, turbidity and paleoenvironment (Ashraf, 2004). The genus Candona, which occurs in fresh water and sediment sequence [15] can be considered as a fresh water and marginal marine equivalent of the genus Krithe. Biostratigraphy and ecological studies on different species of Ostracoda from Bay of Biscay including different genera of Krithe review to deduce the evolution of the Bay [16] (Table 1).

Table 1: A brief review of the studies on Ostracoda genus Krithe from across the world and their corresponding implications.

\begin{tabular}{|c|c|c|c|}
\hline Species & Location & Implication & Reference \\
\hline Krithe cushmani & US Gulf Coastal Plain & Paleoenvironment & Puckett, 1997 [6] \\
\hline Krithe and Parakrithe & East China \& Yellow sea & Paleoenvironment & Zhao \& Whatley, 1997 [7] \\
\hline $\begin{array}{l}\text { Krithe comma, K. dialata,K. pseudocomma, } K . \\
\text { prolata, K. triangularis }\end{array}$ & Southern Austrailia & Paleoceanography & Ayress, et al, 1999 [5] \\
\hline $\begin{array}{l}\text { Krithe reversa, } K . \text { trinidadensis, } K . \text { morkhoveni, } K . \\
\text { gnoma, } K \text {. coimbraisp.nov }\end{array}$ & Brazilian margin & Paleoecology & Carmo and Sanguinetti, 1999.[17] \\
\hline Krithe bartonensis & Gebel Mokkattam, Egypt & Paleoenvironment & Ashraf, 2004 [16] \\
\hline Krithe compressa, Krithe comma & New Zealand & Biostratigraphy & Ayress, 2006 [11] \\
\hline Krithe iniqua, Krithe compressa & Monte San Nichola & Morphometry & Aiello et al, 2007 [14] \\
\hline Multiple species of Krithe & $\begin{array}{l}\text { Eastern Equatorial Pa- } \\
\text { cific }\end{array}$ & Glacial-Interglacial & Stepanova and Lyle, 2014 [3] \\
\hline Krithe sp. & South Indian Ocean & Paleoecology & Cristianini \& Abiraman, 2012 [12] \\
\hline Multiple species of Krithe & Off Turkey coast & Ecology & Ferda et al , 2015 [10] \\
\hline Krithe sp. & Basin of Iceland & Paleosalinity\& Paleotemperature & Benson and Elderfield, 2018 [13] \\
\hline Multiple species of Krithe & Bay of Biscay, Spain & Ecology and Biostratigraphy & Rodriguez-Lazaro et al, 1999 [4] \\
\hline Krithe praetexta praetexta & North Atlantic & Paleoemperature & Yamaguchi, 2018 [9] \\
\hline
\end{tabular}

\section{Conclusion}

The genus is distributed across all the oceans, except for shallow tropical bottom sediments. The wide geographical occurrence of these genera makes them useful in paleooceanographic reconstruction and correlation. Compiling the works on the genus Krithe reveals that the genera thrives on lower temperature $\left(3^{\circ} \mathrm{C}\right)$, moderate salinity and fine grade substrate (clay and silt) favourable for their distribution. Krithe is a better Ostracoda genus in deciphering deep sea temperature evolution and ocean hydrology (except for shallow tropical zones).

\section{References}

1. Smith AJ, Horne DJ, Martens K, Schön I (2015) Class Ostracoda. In: Thorp J, Rogers DC (Eds.), Ecology and General Biology: Thorp and
Covich's Freshwater Invertebrates, Academic Press, United States, pp. 757-780.

2. Nicole Börner, Bart De Baere, Qichao Yang, Klaus Peter Jochum, Peter Frenzel. (2013) Ostracod shell chemistry as a proxy for paleoenvironmental change. Quaternary International 313: 17-37.

3. Stepanova A, Lyle M (2014) Deep Sea Ostracoda from the Eastern Equatorial Pacific (ODP Site 1238) over the last $460 \mathrm{ka}$. Marine Micropaleontology 111: 100-117

4. Rodriguez-Lazaro J, Cronin TM (1999) Quaternary glacial and deglacial Ostracoda in the thermocline of the Little Bahama Bank (NW Atlantic), Paleoceanographic implications. Paleogeography Paleoclimatology Paleoecology 152: 339-364.

5. Ayress MA, Timothy B, Vicki P, Whatley R (1999) Neogene to Recent species of Krithe (Crustacea: Ostracoda) from the Tasman Sea and off southern Australia with description of five new species. Records of Australian Museum 51(1): 1-22. 
6. Puckett TM (1997) The genus Krithe (Ostracoda) from the Campanian and Maastrichtian (Upper Cretaceous) of the northern US Gulf Coastal Palian. Journal of Micropaleontology 16: 145-157.

7. Zhao Q, and Whatley R (1997) Distribution of ostracod genera Krithe and Parakrithe in bottom sediments of the East China and Yellow Sea. Marine Micropaleontology 32(1-2): 195-207.

8. Whatley R, Zhao Q (1993) The Krithe problem: a case history of the distribution of Krithe and Parakrithe (Crustacea, Ostracoda) in South China Sea. Paleogeography, Paleoclimatology, Paleoecology 103(3-4) 281-297.

9. Yamaguchi T (2018) Data report: Eocene-early Oligocene ostracods at IODP Site U1411, off Newfoundland, North Atlantic, Norris RD, Wilson PA, Blum P, and the Expedition 342 Scientists. Proceedings of the Integrated Ocean Drilling Program 342.

10. Ferda P P, Selcuk A, Husamettin B (2015) An updated checklist of recent marine and coastal brackish water ostracods (Crustacea Ostracoda) in Turkey. Journal of Entomology and Zoology Studies 3(3): 20-33.

11. Ayress MA (2006) Ostracod biostratigraphy of the Oligocene- Miocene (upper Waiitakan to lower Otaian) in southern New Zealand. New Zealand Journal of Geology and Geophysics 49(3): 359-373.

12. Cristianini TB, Abiraman G, Eocene-Elmore AC, Sosdian S, Rosenthal Y (2012) A global evaluation of temperature and carbonate ion control on $\mathrm{Mg} / \mathrm{Ca}$ ratios of Ostracoda genus Krithe. Geochemistry Geophysics Geosystems 13(9): 1-20.
13. Benson O, Elderfield $H$ (2018) The distribution and coordination of trace elements in Krithe ostracods and their implications for paleothermometry. Geochimica et Cosmochimica Acta 236: 230-239.

14. Aiello G, Barattalo F, Barra D, Fiorito G, Mazzarella A, et al. (2007) Fractal analysis of Ostracoda shell variability: A comparison with geometric and classic morphometrics. Acta Paleontologica Polonica 52(3): 563-573.

15. Cohuo S, Hernandez C, Perez L, Alcocer J (2017) Candonaalchichica (Podocopida:Candonidae), a new ostracod species from saline, tropical Lake Alchichica, Mexico.J Limnol 76(1): 68-84.

16. Ashraf Elewa MT (2004) Quantitative analysis and paleoecology of Eocene Ostracoda and benthonic Foraminifera from Gebel Mokattam, Cairo, Egypt. Paleogeography, Paleoclimatology, Paleoecology 211:309-323.

17. Ashraf Elewa MT (2004) Quantitative analysis and paleoecology of Eocene Ostracoda and benthonic Foraminifera from Gebel Mokattam, Cairo, Egypt. Paleogeography, Paleoclimatology, Paleoecology 211: 309-323.

18. Carmo DA, Sanguinetti Y T (1999)Taxonomy and palaeoceanographical significance of the Krithe genus in the Brazilian continental margin. Journal of Micropaleontology 18(2): 11-123.

\section{Your next submission with Juniper Publishers will reach you the below assets}

- Quality Editorial service

- Swift Peer Review

- Reprints availability

- E-prints Service

- Manuscript Podcast for convenient understanding

- Global attainment for your research

- Manuscript accessibility in different formats

( Pdf, E-pub, Full Text, Audio)

- Unceasing customer service

Track the below URL for one-step submission https://juniperpublishers.com/online-submission.php 